\title{
Proses Kreatif Peserta Pameran Seni Rupa Tjergam Taroeng di Galeri Nasional Jakarta
}

\author{
Kurnia Setiawan \\ Universitas Tarumanagara \\ kurnias@fsrd.untar.ac.id
}

\begin{abstract}
Abstrak- Komik Indonesia banyak dipengaruhi oleh budaya luar yang masuk ke Indonesia seperti; tokoh, penceritaan, dan gaya visual, meskipun begitu para komikus Indonesia memiliki kreativitas untuk mengembangkannya sehingga memiliki ciri khas Indonesia. Komik Indonesia mengalami pasang surut sejalan dengan perubahan zaman. Patut disayangkan para tokoh komik Indonesia yang dulu sangat terkenal, bahkan sempat difilmkan, kemudian seolah mati suri atau tidak lagi dikenal oleh generasi saat ini. Para dosen dari berbagai perguruan tinggi di Jakarta yang tergabung dalam kelompok Jagad Roepa, berinisiatif untuk mengangkat tema "Tjergam Taroeng" pada pameran perdana mereka di Galeri Nasional pada tanggal 12 22 Agustus 2016. Selain berkarya lewat pameran, juga dilakukan penelitian sehubungan dengan kegiatan pameran yang akan dilakukan. Penelitian ini bertujuan merekam proses kreatif para peserta pameran dan proses pameran "Tjergam Taroeng". Desain penelitian ini adalah deskriptif kualitatif, dengan melibatkan 12 orang subyek penelitian sebagai informan kunci yang dipilih dengan metode purposive sampling, yaitu para dosen peserta pameran. Metode pengumpulan yang digunakan adalah wawancara dan observasi. Penelitian dilakukan di Jakarta pada bulan Juli - Desember 2016. Hasil penelitian berupa analisis proses kreatif dan pendokumentasian pameran "Tjergam Taroeng".
\end{abstract}

Kata kunci: pameran seni rupa; komik; proses kreatif; deskriptif-kualitatif

\section{PENDAHULUAN}

Perubahan zaman terus terjadi, setelah mengalami masa revolusi agraria, industri, dan teknologi informasi (era globalisasi), saat ini kita memasuki zaman konseptual (Pink, 2007). Pada masa ini, kekuatan ekonomi bukan lagi pada sumberdaya alam tetapi pada ide atau kreativitas (Sudarma, 2013, hal. 11). Salah satu bidang yang masuk dalam daftar 14 industri kreatif, termasuk di dalamnya adalah seni rupa dan desain. Salah satu peminatan/ fokus pada bidang seni rupa dan desain adalah komik. Para perupa yang tergabung dalam kelompok Jagad Roepa Studio Enam, Fakultas Seni Rupa dan Desain Universitas Tarumanagara berinisiatif menanggapi komik Indonesia yang pernah berjaya pada kurun 1960 - 1980an dengan judul pameran
Tjergam Taroeng. Karya seni rupa yang dipamerkan berbentuk lukisan, instalasi, patung di Galeri Nasional pada bulan Agustus 2016. Pemahaman 'taroeng' atau pertarungan yang ditawarkan dalam pameran seni rupa ini lebih kepada wacana karya yang akan dikemas dalam perhelatan dunia seni 'tjergam'. Adapun kata 'tjergam' merupakan ejaan lama dari kata cergam, singkatan dari cerita bergambar. Kata 'taroeng' tidak hanya bermakna pertarungan secara fisik antara tokoh baik dan buruk di dunia persilatan saja. Tarung dalam pameran ini dapat juga bermakna lebih simbolik dan luas. Tarung dapat bermakna sebuah dialektika antara segala ekspresi budaya timur dan barat, baru dan lama, muda dan tua. Bahkan dalam konteks sosial-politik pun dapat berkembang 
menjadi dialektika antara penegakan hukum melawan pelanggaran hukum seperti kasus korupsi, dan sebagainya.

Tujuan Penelitian ini untuk mengungkapkan proses kreatif yang dilakukan oleh para perupa pameran Tjergam Taroeng, yang juga adalah pengajar di fakultas seni rupa dan desain. Di zaman konseptual, kita perlu menguasai enam kemampuan dasar dari pemikiran berorientasi otak kanan sehingga dapat membantu kita mempunyai pemikiran baru yang utuh (keseimbangan antara otak kiri dan kanan). Enam indera itu adalah; (1) desain, (2) cerita, (3) simfoni, (4) empati, (5) bermain, (6) makna (Pink, 2007, hal. 65-67). Dalam diri seniman (perupa) selalu ada dualisme. Di satu sisi adalah manusia dengan kehidupan 'personal', di sisi lain ia adalah sebuah proses kreatif yang 'impersonal'. Menurut Jung, seni adalah semacam dorongan bawaan (innate drive) yang menyergap sisi kemanusiaan seniman dan menjadikannya sebagai instrument atau alat. Seniman bukan lagi seseorang yang mempunyai kehendak bebas untuk mencapai tujuannya melalui dirinya, ia membiarkan seni memanfaatkan dirinya, terutama bagi seniman yang berkarya berdasarkan impulsi dan karyanya tergolong visioner (Harbunangin, 2016, hal.105).

Hasil penelitian dapat langsung diaplikasikan untuk kepentingan pendidikan, khususnya seni rupa dan desain, melalui mata kuliah yang membahas tentang kreativitas di perguruan tinggi masing-masing. Dokumentasi pameran Tjergam Taroeng dapat menjadi bagian dari dokumen peristiwa kesenirupaan, khususnya berkenaan dengan pameran seni rupa untuk menanggapi gejala pertentangan tradisi dan budaya populer.

\section{METODE}

Penelitian ini adalah deskriptif kualitatif. Subyek penelitian yang bertindak sebagai partisipan dipilih dengan metode purposive sampling yang dipilih berdasarkan kriteria tertentu, yaitu para dosen peserta pameran Tjergam Taroeng. Peneliti juga terlibat sebagai bagian dari kelompok Jagad Roepa (peserta pameran) sehingga penelitian ini merupakan participatory research. Penelitian ini dilakukan di Fakultas Seni Rupa dan Desain Universitas Tarumanagara dan Galeri Nasional, Jakarta pada bulan April September 2016. Instrumen penelitian yang digunakan adalah: alat perekam gambar dan suara, peralatan tulis, dan keperluan pelengkapnya. Analisis data dilakukan berdasarkan verbatim transkripsi hasil wawancara para perupa (in depth interview) dan obeservasi selama kegiatan pameran berlangsung. Hasil penelitian bukan saja berbentuk laporan, melainkan dikemas dalam bentuk dokumentasi foto/ video. 


\section{HASIL DAN PEMBAHASAN}

Kelompok Djagat Roepa Studio Enam, FSRD Universitas Tarumanagara menyelenggarakan perhelatan pameran seni rupa di gedung B, Galeri Nasional Jakarta yang berjudul Tjergam Taroeng. Pembukaan pameran pada 12 Agustus 2016. Pameran diselenggarakan pada 13 hingga 22 Agustus 2016. Pembukaan pameran oleh Prof. Dr. Sarlito Wirawan Sarwono. Adapun saat tulisan ini diterbitkan beliau telah wafat. Pameran Tjergam Taroeng dikurasi oleh Kuss Indarto. Pada Sabtu, 20 Agustus 2016 pukul 13.00 WIB diadakan Obrolan Perupa di Ruang Seminar Gedung B Galeri Nasional Jakarta, dengan tujuan membagi pengalaman apa yang telah dikerjakan selama kurang lebih enam bulan berkarya.

Analisa penerapan konsep dan proses kreatif para perupa berdasarkan enam indera kreatif menurut Dainel Pink; (1) desain, (2) cerita, (3) simfoni, (4) empati, (5) bermain, (6) makna, dijelaskan dibawah ini:

\begin{tabular}{|c|c|c|c|}
\hline No & $\begin{array}{l}\text { Nama } \\
\text { Perupa }\end{array}$ & $\begin{array}{c}\text { Konsep Karya dan } \\
\text { Proses Kreatif }\end{array}$ & $\begin{array}{c}\text { Karya } \\
\text { Pameran }\end{array}$ \\
\hline 1 & $\begin{array}{l}\text { Abidin M } \\
\text { Noor }\end{array}$ & $\begin{array}{l}\text { Penekanan pada aspek cerita } \\
\text { tentang Jaka Sembung dengan } \\
\text { sudut pandang yang berbeda. } \\
\text { Ide berasal dari refleksi pribadi } \\
\text { berdasarkan cerita Jaka } \\
\text { Sembung yang ditampilkan } \\
\text { dengan sudut padang ektrem, } \\
\text { yaitu sudut padang yang hanya } \\
\text { menampilkan kaki pendekar. }\end{array}$ & $\begin{array}{l}\text { Lukisan; Tjekam } \\
\text { Jelang Taroeng } \\
\text { Instalasi; koin } \\
\text { Parmin }\end{array}$ \\
\hline 2 & $\begin{array}{l}\text { Ananta O' } \\
\text { Edan }\end{array}$ & $\begin{array}{l}\text { Penekanan pada aspek cerita } \\
\text { melalui deformasi petruk dalam } \\
\text { konteks kekinian. Inspirasi dari } \\
\text { tokoh Petruk digabungkan } \\
\text { dengan hobinya pada motor } \\
\text { besar. }\end{array}$ & $\begin{array}{l}\text { Lukisan ; Patroli } \\
\text { Bedebah } \\
\text { Instalasi : si Buta } \\
\text { dari gua hantu }\end{array}$ \\
\hline
\end{tabular}

\begin{tabular}{|c|c|c|c|}
\hline 3 & \begin{tabular}{|l} 
Andre \\
Random
\end{tabular} & $\begin{array}{l}\text { Penekanan pada aspek makna } \\
\text { melalui tampilan visual yang } \\
\text { memiliki pesan khusus tentang } \\
\text { kondisi kekinian melalui } \\
\text { perspektif tokoh superhero } \\
\text { lawas. Inspirasi berasal dari kata } \\
\text { "taroeng" yang dimaknai } \\
\text { menjadi apa saja pertarungan } \\
\text { yang terjadi saat ini. }\end{array}$ & $\begin{array}{l}\text { Lukisan (1) } \\
\text { Comfort Zone } \\
\text {;(2) Keep Calm; } \\
\text { (3) Fusion } \\
\text { Instalasi } \\
\text { Panel karya }\end{array}$ \\
\hline 4 & Iqbal Oemar & $\begin{array}{l}\text { Penekanan pada aspek cerita } \\
\text { dan makna melalui tampilan } \\
\text { tokoh Godam dalam hidup } \\
\text { keseharian. Ide berasal dari rasa, } \\
\text { ekspresi dan kenangan masa } \\
\text { kecil yang dimunculkan melalui } \\
\text { dirinya menjadi Superhero } \\
\text { dalam keseharian. }\end{array}$ & $\begin{array}{l}\text { Lukisan ; (1) } \\
\text { Semua bisa jadi } \\
\text { Godam (2) } \\
\text { Gundala juga } \\
\text { Ngonthel }\end{array}$ \\
\hline 5 & $\begin{array}{l}\text { Kurnia } \\
\text { Setiawan }\end{array}$ & $\begin{array}{l}\text { Penekanan pada aspek desain } \\
\text { dan simfoni, melalui tampilan } \\
\text { karya berbentuk utama instalasi } \\
\text { yang merupakan perpaduan } \\
\text { berbagai aspek. Ide didahului } \\
\text { dengan riset tentang tema dan } \\
\text { dilanjutkan dengan refleksi akan } \\
\text { kata "taroeng" yang dapat } \\
\text { didekonstruksi menjadi saatnya } \\
\text { untuk bersinergi (harmoni). }\end{array}$ & $\begin{array}{l}\text { Instalasi kitiran } \\
\text { angin : Sinergi } \\
\text { Panel karya (3) }\end{array}$ \\
\hline 6 & $\begin{array}{l}\text { Leonard } \\
\text { Pratama }\end{array}$ & $\begin{array}{l}\text { Penekanan pada aspek desain } \\
\text { dan makna, melalui tampilan } \\
\text { karya yang mirip poster dengan } \\
\text { teks dan visual yang } \\
\text { menyampaikan pesan tertentu. }\end{array}$ & $\begin{array}{l}\text { Lukisan; (1) } \\
\text { Dijual: Gambar } \\
\text { Umbul; (2) } \\
\text { Dijual: Lukisan; } \\
\text { (3) Service } \\
\text { Arloji Langka; } \\
\text { (4) Revolusi } \\
\text { Mental } \\
\text { Indonesia }\end{array}$ \\
\hline 7 & $\begin{array}{l}\text { Nashir } \\
\text { Setiawan }\end{array}$ & $\begin{array}{l}\text { Penekanan pada aspek bermain, } \\
\text { melalui gaya visual dan } \\
\text { penggabungan setting } \\
\text { punakawan Indonesia dan } \\
\text { kostum superhero Barat. } \\
\text { Inspirasi berasal dari tokoh } \\
\text { punakawan Indonesia. }\end{array}$ & $\begin{array}{l}\text { Lukisan : (1) Ojo } \\
\text { Dumeh; (2) } \\
\text { Super Gareng }\end{array}$ \\
\hline 8 & $\begin{array}{l}\text { Muchyar } \\
\text { Sumpena }\end{array}$ & $\begin{array}{l}\text { Penekanan pada aspek makna } \\
\text { melalui tokoh punakawan dalam } \\
\text { konteks situasi kekinian. Ide } \\
\text { berupa kritik sosial yang } \\
\text { ditampilkan melalui tokoh } \\
\text { Semar dan Petruk. }\end{array}$ & $\begin{array}{l}\text { Lukisan : (1) } \\
\text { Semar Masgul } \\
\text { (2) Petruk Naik } \\
\text { Unta }\end{array}$ \\
\hline 9 & $\begin{array}{l}\text { Toto M } \\
\text { Mukmin }\end{array}$ & $\begin{array}{l}\text { Penekanan pada aspek makna, } \\
\text { melalui intepretasi simbolik } \\
\text { terhadap konteks situasi } \\
\text { kekinian melalui perspektif } \\
\text { superhero lawas. Inspirasi } \\
\text { berasal dari kata "taroeng" yang } \\
\text { dimaknai adalah pertarungan } \\
\text { apa saja yang terjadi saat ini }\end{array}$ & $\begin{array}{l}\text { Lukisan : (1) } \\
\text { Superhero dan } \\
\text { Tikus Bedebah } \\
\text { (2) Menanam } \\
\text { Anak Garuda }\end{array}$ \\
\hline 10 & \begin{tabular}{|l|} 
Untung \\
Saryanto
\end{tabular} & $\begin{array}{l}\text { Penekanan pada aspek empati } \\
\text { (rasa) dan cerita melalui refleksi } \\
\text { kegelisahan perupa yang } \\
\text { ditampikan melalui karyanya. } \\
\text { Inspirasi berasal dari dirinya } \\
\text { sendiri yang diekspresikan } \\
\text { melalui Bagong. }\end{array}$ & $\begin{array}{l}\text { Lukisan : } \\
\text { Bagong Bukan } \\
\text { Bagong (3) }\end{array}$ \\
\hline
\end{tabular}




\begin{tabular}{|l|l|l|l|}
\hline 11 & Yassir Malik & $\begin{array}{l}\text { Penekanan pada aspek makna } \\
\text { melalui rekontekstualisasi para } \\
\text { superhero lawas dalam dimensi } \\
\text { kekinian. Inspirasi berasal dari } \\
\text { superhero favorit dan budaya } \\
\text { baru (konteks kekinian). }\end{array}$ & $\begin{array}{l}\text { Lukisan : (1) Last } \\
\text { Piyama Badra (3 } \\
\text { Halo, Suwe Ora } \\
\text { Jamu } \\
\text { Panel Karya ; } \\
\text { sketsa kertas (3) }\end{array}$ \\
\hline 12 & Yuli Asmanto & $\begin{array}{l}\text { Penekanan pada aspek empati, } \\
\text { rekontestualisasi komik si Buta } \\
\text { dengan visual (marah) disertai } \\
\text { teks yang menggugah emosi dan } \\
\text { visualisasi surat si Buta kepada } \\
\text { kekasihnya. Inspirasi berasal dari } \\
\text { ketokohan (jagoan si Buta) dan } \\
\text { filosofi narasi yang ditampilkan } \\
\text { dalam bentuk karya visual } \\
\text { mengikuti teks }\end{array}$ & Marah; (2) \\
Surat untuk \\
Marni \\
Instalasi \\
\hline
\end{tabular}

Tabel 1: Konsep Karya dan Proses Kreatif Para Peserta Pameran

Penerapan konsep dan proses kreatif para perupa berdasarkan enam indera kreatif paling banyak adalah berkenaan dengan makna (6 orang) dan cerita (3 orang). Sisanya desain dan empati 2 orang, simfoni dan bermain 1 orang.

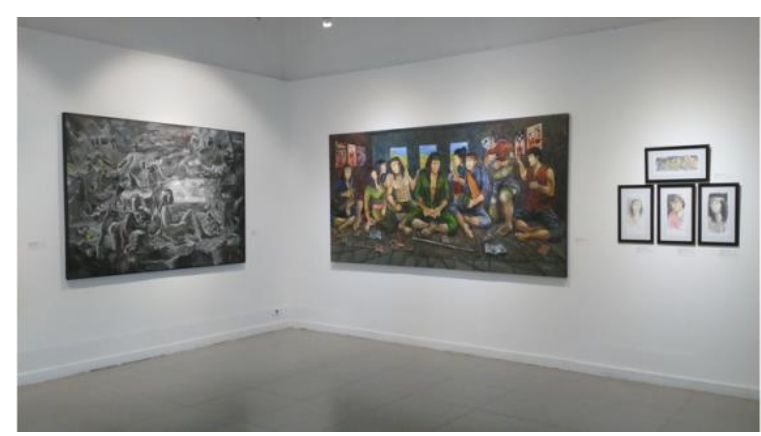

Gambar 1. Ruang Pamer 1 Pameran Tjergam Taroeng (Sumber: dokumentasi pribadi

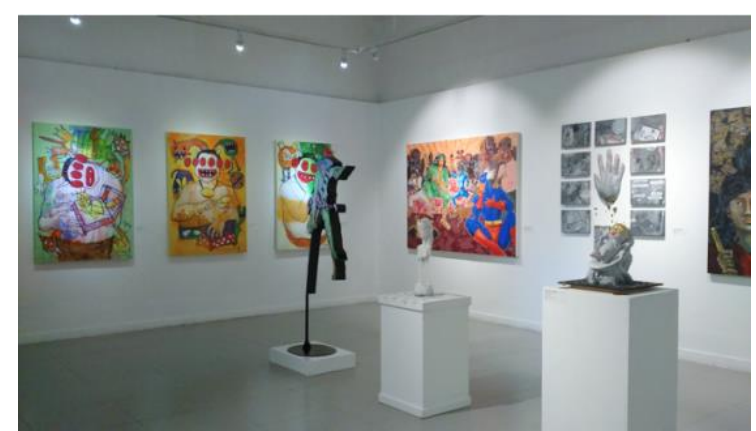

Gambar 2. Ruang Pamer 2 Pameran Tjergam Taroeng (Sumber Dokumentasi Pribadi)

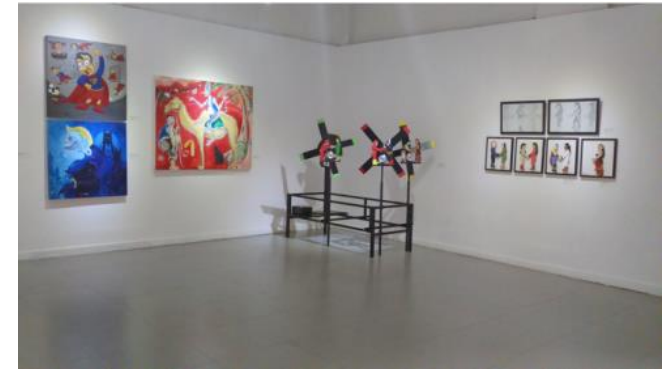

Gambar 2. Ruang Pamer 3 Pameran Tjergam Taroeng (Sumber Dokumentasi Pribadi)

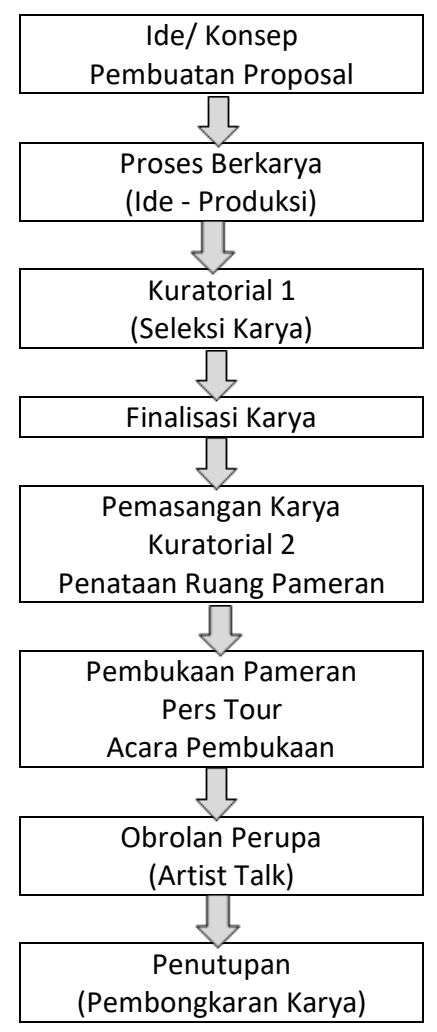

Gambar 4. Alur proses persiapan dan pelaksanaan pameran

\section{SIMPULAN}

Para perupa peserta pameran mampu mengaplikasikan indera kreatif mereka untuk berkarya, terutama melalui proses kreatif eksplorasi makna dan melakukan rekontekstualisasi cerita para tokoh di dalam Pameran Tjergam Taroeng. Ide dasar cerita bergambar 
yang bersifat popular dapat direspon menjadi suatu karya seni rupa yang memiliki pesan dan makna dalam konteks kekinian. Bagi sebagian perupa seolah ada semacam dorongan bawaan (innate drive) yang menjadikan diri mereka sebagai sarana untuk menyampaikan pesan melalui karya mereka. Karya pameran Tjergam Taroeng merupakan perpaduan antara intelek (logika) dan intuisi (rasa). Para perupa mampu bersikap terbuka, berani bereksperimen dalam mengolah tema yang ada.

Pelaksanaan Pameran Tjergam Taroeng dapat dikatakan berhasil bila dilihat dari variabel waktu pameran. Awalnya rencana pameran sepuluh hari, diperpanjang menjadi 14 hari oleh pihak Galeri Nasional karena minat pengunjung yang tinggi. Selama dua minggu berpameran, jumlah pengunjung yang tercatat lebih dari 8000 (delapan ribu) orang dan diliput lebih dari 20 (dua puluh) media online/cetak.

Adapun pendokumentasian kegiatan pameran mulai dari persiapan sampai dengan pelaksanaan dapat menjadi model/ acuan untuk kegiatan sejenis berikutnya.

\section{DAFTAR PUSTAKA}

Ahmad, Hafiz, Alvanov Zpalazani, Beni Maulana. (2005). Keliling Komik Dunia. Jakarta : Gramedia
Harbunangin, Buntje, (2016). Art \& Jung; Seni dalam Sorotan Psikologi Analitis Jung. Jakarta : Antara Publishing

Momon. Sudarma, (2013). Mengembangkan Ketrampilan Berpikir Kreatif. Jakarta : Rajawali Pers

Kowa, Frans (ed). (2003). Seri Kekayaan Tersembunyi; Sukses Mengksplorasi Seni. Jakarta : Penerbit Buku Kompas

Pink, Daniel H. (2007). A Whole New Mind. Yogyakarta : ThinkSudarma, 